\title{
QUANTIFYING SOIL TILTH FOR WHEAT AND Faba bean CROPS USING TILTH INDEX
}

\author{
(Recieved8.1.2009) \\ By \\ M. A.El-Nady and M.F.,Abo Youssef * \\ Soil Science Department, Faculty of Agriculture, Cairo University, \\ and *Soil Conservation Department, Desert Research Center, Cairo, Giza, Egypt
}

\begin{abstract}
One of the factors critical to seed germination and plant development is good tilth. This study was conducted to calculate the tilth index (T1) under different tillage practices and two crops, wheat and faba bean in order to determine the optimum tilth index value for maximum yield of wheat and faba bean crops. Tillage practices applied were traditional tillage by different chisel ploughing passes $\{$ two (P2), four (P4), six (P6) and eight passes (P8) \} and moldboard plough (Pm). Tilth index was calculated following the model suggested by Singh et al., (1992). Five soil physical properties, soil bulk density, cone index, aggregate uniformity coefficient organic matter content, and plasticity index were determined for each tillage system to quantify (T1) according to the model. The calculated values of the tilth index were varied with tillage practices. The tilth index increased as ploughing passes increased. Tilth index increased from 0.52 to 0.67 under (P2) and (P8), respectively. However, the highest value was obtained with the moldboard plough (0.71).Yield of wheat and Faba bean also varied according to the tillage practices and to the (TI) values. The highest yield of wheat was obtained with (Pm) treatment which corresponds to (TI) value of 0.71, while Faba bean yield increased with (P6) treatment which corresponds to (TI) value of 0.59.It is concluded that the tilth index can be used to describe the physical conditions of the soil and as an indicator for the most effective tillage practices that achieve the maximum yield for a certain crop.
\end{abstract}

Key words: Faba bean yield, soil physical properties, tilth index, wheat yield.

\section{INTRODUCTION}

Tillage plays an important part in the preparation of the seed bed for germination and plant growth. Soil physical conditions following tillage may vary according to tillage systems applied. De Costa et al. (1997), stated that one of the most influential technical factors on the outcome of a crop is the tillage method since it changes both the physical properties and moisture content of the soil. Tillage method affects the sustainable use of soil resources through its influence on soil properties (Hammel, 1989). Tilth has been viewed as a qualitative term describing the physical state of soil in terms of ease of tillage, seed bed preparation, seedling emergence and root growth (Brady, 1984 and Plaster, 1985). Karlen et al. (1990) defined soil tilth as the physical conditions of a soil described by its bulk density, porosity, structure, roughness, and aggregate characteristics as related to water, nutrient, heat, impedance to seedling emergence and root penetration. They also added that plant growth can be used as an indicator of soil tilth because it integrates the effects of crop, soil, and microenvironment.

Tapela and Colvin, (2002) stated that the tilth or soil condition resulting from the use of different tillage tools depends on both the type of implement used and the soil condition when tillage occurs. They also indicated that benefits of tillage are well known, but the proper tillage needed to achieve optimum soil conditions is not well understood. Cruse and Colvin (1989), however, reported that some tillage is needed but excessive tillage may not be helpful. They also added that unnecessary tillage operations not only consume energy needlessly, but can aggravate soil erosion, and reduce long term production capabilities. Tapela and Colvin (1998) reported that if tillage results and soil conditions were quantifiable, it would be easier to determine the amount of tillage necessary to achieve an optimal yield level. 
Schafer et al. (1985) reported that quantification of soil tilth may help in evolving custom-prescribed tillage. Gupta (1986) used a single composite physical index to quantify soil tilth as a product of the rating of eight physical properties included soil depth, bulk density, infiltration rate or apparent hydraulic conductivity, available water storage capacity, organic matter content, non-capillary pore space, water table depth and slope. Singh, (1991) believed that if soil properties were optimized; the tilth then would also be optimum. He also added that to identify the tillage practice that produce adequate tilth for the maximum yield production, the tilth index is a good quantitative value that can be used to describe soil conditions that relate to plant growth.

Singh and Colvin (1992) stated that there is a need for a quantitative understanding of soil tilth to help scientists, engineers, and farmers for better understand how to manage soil. They developed the tilth index as a multiplicative combination of tilth coefficients for soil parameters of bulk density, cone index, aggregates uniformity coefficient, organic matter and plasticity index.

Tilth index (TI) has been used to describe soil conditions ranging from 0.0 for worst to 1.0 for best soil conditions as related to crop production. It can be used for tillage management to avoid unnecessary tillage operations beyond an optimum
Faculty of Agriculture, Cairo University. Five tillage treatments were used i.e., chisel ploughing by two (P2), four (P4), six (P6) and eight (P8) passes and the moldboard ploughing $(\mathrm{Pm})$. The experimental design was a randomized complete block design with three replicates. The plot size was $100 \mathrm{~m}^{2}(5 \times 20 \mathrm{~m})$. Wheat (Triticum aestivum L.), c.v. Sds1 and faba bean (Vicia faba L.), c.v. Giza3 were planted on Nov.26, 2006. Wheat was sown in rows at a distance of $15 \mathrm{~cm}$ between rows. Faba bean was sown at a distance of $30 \mathrm{~cm}$ between rows and $25 \mathrm{~cm}$ apart. Fertilizers were applied according to the recommended doses of the Ministry of Agriculture. Some physical characteristics of the experimental soil were determined and given in Table (1). Soil physical properties measured for the determination of the (TI) were: bulk density (BD) according to Klute, (1986) using the core method, soil penetration resistance (CI) by using the penetrologger with a cone type of $1 \mathrm{~cm}^{2}$ and an angle of $60^{\circ}$, organic matter $(\mathrm{OM})$ by the modified Walkley and Black method (Page et al., 1982), aggregate uniformity coefficient (AUC) according to Jumikis, (1962) and the plasticity index (PI) according to Liu and Evett, (1990). Soil samples were taken after the establishment of the tillage practices from the 0 $15 \mathrm{~cm}$ soil depth for the measurements of the previous soil properties. Grain yield of each crop

Table (1): Some physical and chemical characteristics of the experimental soil site.

\begin{tabular}{|c|c|c|c|c|c|c|}
\hline \multirow{2}{*}{$\begin{array}{c}\text { Soil depth } \\
(\mathrm{cm})\end{array}$} & \multicolumn{3}{|c|}{$\begin{array}{c}\text { Particle size distribution } \\
(\%)\end{array}$} & Texture class & ECe (dS.m $\left.{ }^{-1}\right)$ & \\
\cline { 2 - 4 } & Sand & Silt & Clay & & & pH \\
\hline $0-20$ & 41.6 & 36.8 & 21.6 & Loam & 1.23 & 7.62 \\
\hline $20-40$ & 45.8 & 30.5 & 23.7 & Loam & 1.42 & 7.84 \\
\hline
\end{tabular}

tilth. A value of (TI) between 0.8 and 1.0 was found optimal for crop production, (Singh et al., 1992). They suggested that the relations could be used over a variety of soil and climatic conditions and management practices, after further testing.

Abou Youssef (2005) found that tilth indices of individual soils ranged from 0.507 for no-tillage to 0.852 for moldboard tillage. $\mathrm{He}$ also found a strong correlation between (TI) and yield of soybean under different tillage systems. Tripathi et al. (2005) reported that wheat yield increased linearly with increasing (TI) from 0.75 to 0.89 .

\section{MATERIALS AND METHODS}

\subsection{Experimental details}

This experiment was conducted at the Agriculture experimental and Research Station, was recorded after harvesting.

\subsection{Tilth index calculation}

Tilth index was calculated for each tillage treatment using the model developed by Singh et al. (1992). The model utilizes bulk density, cone index, organic matter content, aggregate uniformity coefficient and plasticity index as parameters for calculating tilth index. According to the model, the tilth index is a multiplicative combination of tilth coefficients expressed as: TI $=\mathrm{CF}_{1} \times \mathrm{CF}_{2} \ldots \times \mathrm{CFn}$

Where, TI is the tilth index $(0.0 \leq \mathrm{TI} \leq 1.0)$, $\mathrm{CF}$ the tilth coefficient and $n$ is the number of soil properties used for calculation of the tilth index.

The equations used to calculate tilth coefficients for each soil property according to the model of Singh et al. (1992) are as follows: 


$$
\begin{aligned}
& \mathrm{CF}(\mathrm{BD})=-1.5+3.87 \mathrm{BD}-1.5 \mathrm{BD}^{2} \\
& \mathrm{CF}(\mathrm{CI})=1.012-0.002 \mathrm{CI}-0.01 \mathrm{CI}^{2} \\
& \mathrm{CF}(\mathrm{OM})=0.59+0.122 \mathrm{OM}-0.008 \mathrm{OM}^{2} \\
& \mathrm{CF}(\mathrm{AUC})=0.35+0.245 \mathrm{AUC}-0.023 \mathrm{AUC}^{2} \\
& \mathrm{CF}(\mathrm{PI})=1.02+0.0009 \mathrm{PI}-0.00016 \mathrm{PI}^{2}
\end{aligned}
$$

The non-limiting and critical values of tilth coefficients, assigned by Singh et al. (1992), for the soil properties are given in Table (2). reported greater bulk density and soil penetration resistance in no-till compared with moldboard plow and chisel plow during the early and mid season corn growth (Vyn and Raimbault, 1993 and Cassel et al., 1995). The moldboard plough decreased (BD) and (PR) as compared to chisel plough by two, four and six passes. The difference in (BD) and in (PR) between (P2) and (P4) was

Table (2): The non-limiting and critical values of tilth coefficients (CF) for each soil property.

\begin{tabular}{|l|l|l|}
\hline Soil properties & Non-limiting values of CF & Critical values of CF \\
\hline Bulk density, BD $(\mathrm{g} . \mathrm{cm}-3)$ & 1.0 for $\mathrm{BD} \leq 1.3 \mathrm{~g} . \mathrm{cm}-3$ & $1.3 \leq \mathrm{BD} \leq 2.1 \mathrm{~g} . \mathrm{cm}-3$ \\
\hline Cone index, CI $\mathrm{MPa})$ & 1.0 for $\mathrm{CI} \leq 1.0 \mathrm{MPa}$ & $1.0 \leq \mathrm{CI} \leq 10 \mathrm{MPa}$ \\
\hline Organic matter, OM $(\%)$ & 1.0 for $\mathrm{O} . \mathrm{M} \geq 5 \%$ & $1.0 \% \leq \mathrm{OM} \leq 5 \%$ \\
\hline $\begin{array}{l}\text { Aggregate uniformity } \\
\text { coefficient, AUC }\end{array}$ & 1.0 for $\mathrm{AUC} \geq 5$ & $2.0 \leq \mathrm{AUC} \leq 5$ \\
\hline Plasticity index, PI $(\%)$ & 1.0 for $\mathrm{PI} \leq 15 \%$ & $15.0 \% \leq \mathrm{PI} \leq 40 \%$ \\
\hline
\end{tabular}

\section{RESULTS AND DISCUSSION}

\subsection{Soil physical properties}

Soil physical properties and the (AUC) of the different tillage treatments are shown in Table (3 and 4) and Fig.(1).It is observed that bulk density $(\mathrm{BD})$ and penetration resistance (PR) values were not significant. However, the differences between both (P2) and (P4) and the other tillage treatments were significant. The changes of soil organic matter content $(\mathrm{OM})$ among treatments were

\begin{tabular}{|c|c|c|c|c|}
\hline Tillage treat. & $\begin{array}{c}\text { Bulk density } \\
\left.\text { (g.cm- }^{3}\right)\end{array}$ & $\begin{array}{c}\text { Penetration } \\
\text { resistance (MPa) }\end{array}$ & $\begin{array}{c}\text { Organic } \\
\text { matter }(\%)\end{array}$ & $\begin{array}{l}\text { Plasticity } \\
\text { index }\end{array}$ \\
\hline P2 & 1.46 & 2.15 & 1.89 & \multirow{6}{*}{21.52} \\
\hline P4 & 1.42 & 1.96 & 1.82 & \\
\hline $\mathrm{P} 6$ & 1.32 & 1.46 & 1.68 & \\
\hline P8 & 1.23 & 1.01 & 1.43 & \\
\hline $\mathrm{Pm}$ & 1.27 & 1.29 & 1.75 & \\
\hline L.S.D. 0.05 & 0.056 & 0.209 & 0.109 & \\
\hline
\end{tabular}
small. Plasticity index (PI) is related to texture and does not change with management practices;

Table (3): Effect of tillage treatments on bulk density, penetration resistance, organic matter and plasticity index.

Table (4): Effect of tillage treatments on aggregate size distribution.

\begin{tabular}{|l|l|l|l|l|l|l|}
\hline $\begin{array}{l}\text { Tillage } \\
\text { treat. }\end{array}$ & \multicolumn{5}{|c|}{ Aggregate size distribution (\%) } \\
\cline { 2 - 7 } & $\begin{array}{l}\mathbf{4 . 0 - 2 . 0} \\
(\mathbf{m m})\end{array}$ & $\begin{array}{l}\mathbf{2 . 0 - 0 . 8 5} \\
(\mathbf{m m})\end{array}$ & $\begin{array}{l}\mathbf{0 . 8 5 - 0 . 4 2} \\
(\mathbf{m m})\end{array}$ & $\begin{array}{l}\mathbf{0 . 4 2 - 0 . 2 5} \\
(\mathbf{m m})\end{array}$ & $\begin{array}{l}<0.25 \\
(\mathbf{m m})\end{array}$ & AUC \\
\hline P2 & $\mathbf{6 . 8 4}$ & $\mathbf{8 . 4 9}$ & $\mathbf{1 3 . 2 8}$ & $\mathbf{1 5 . 6 3}$ & $\mathbf{5 5 . 7 6}$ & $\mathbf{2 . 0 1}$ \\
\hline P4 & $\mathbf{1 0 . 8 3}$ & $\mathbf{8 . 7 9}$ & $\mathbf{1 1 . 5 1}$ & $\mathbf{1 6 . 1 3}$ & $\mathbf{5 2 . 7 4}$ & $\mathbf{2 . 1 2}$ \\
\hline P6 & $\mathbf{1 6 . 9 4}$ & $\mathbf{1 9 . 1 0}$ & $\mathbf{1 7 . 5 1}$ & $\mathbf{1 8 . 2 4}$ & $\mathbf{2 8 . 2 1}$ & $\mathbf{2 . 4 1}$ \\
\hline P8 & $\mathbf{9 . 7 3}$ & $\mathbf{2 2 . 0 5}$ & $\mathbf{1 9 . 8 4}$ & $\mathbf{9 . 1 4}$ & $\mathbf{3 9 . 2 4}$ & $\mathbf{3 . 4 9}$ \\
\hline Pm & $\mathbf{1 2 . 7 5}$ & $\mathbf{2 8 . 7 4}$ & $\mathbf{2 0 . 1 5}$ & $\mathbf{1 2 . 4 5}$ & $\mathbf{2 5 . 9 1}$ & $\mathbf{3 . 7 5}$
\end{tabular}

decreased as ploughing passes increased. The lowest values were obtained under (P8) treatment while the highest values were recorded under $(\mathrm{P} 2)$ treatment. The decrease of soil bulk density after tillage may be due to the break down of soil compaction and the increase of the soil pore spaces (Taieb, 1998). Soil penetration resistance varied with the tillage treatments as a result of the changes in soil bulk density. Many researchers therefore the tilth coefficient for plasticity was the same for all tillage treatments. Aggregate size distributions were expressed in terms of the aggregate uniformity coefficient (AUC), which is the ratio of $D_{60}$ to $D_{10}$ where $D_{60}$ and $D_{10}$ are the diameters, at which $60 \%$ and $10 \%$ of the soil mass is finer, respectively, (Hillel, 1982, Wray, 1986). Singh et al.(1992) reported that any soil with an aggregate uniformity coefficient greater than or 
equal to five was considered to be non-limiting, and one with a value less than or equal to two was considered unusable by plants. faba bean yield showed a significant difference between (P6) and all other treatments. These results indicate that wheat crop under either the

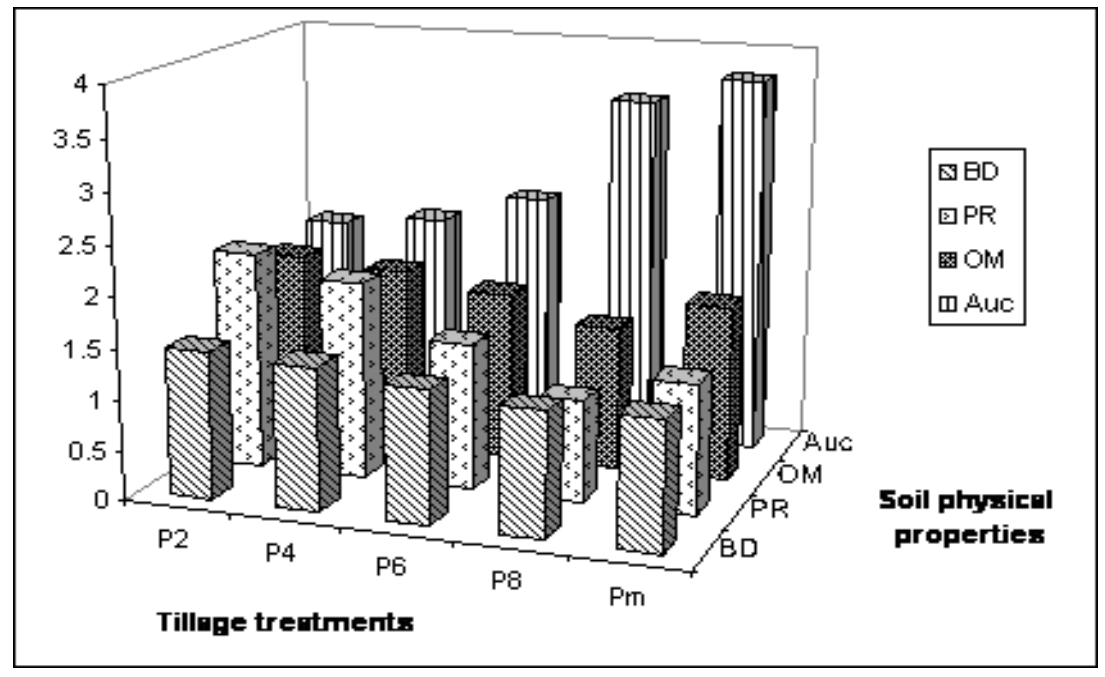

Fig . (1): Soil physical properties as affected by tillage treatments.

\subsection{Tillage and crop performance}

Grain yield of wheat and faba bean are presented in Table (5). The response of wheat and faba bean yield is varied with the applied tillage practices. The highest grain yield of wheat was obtained with (Pm) followed by (P8), (P6), (P4) and $(\mathrm{P} 2)$, respectively. While, the highest grain yield of faba bean was obtained with (P6)

Table (5): Tilth index and yield of wheat and faba bean as affected by the tillage treatments.

\begin{tabular}{|c|c|c|c|}
\hline \multirow{2}{*}{$\begin{array}{l}\text { Tillage } \\
\text { treat. }\end{array}$} & \multicolumn{2}{|c|}{ Yield (kg/fed.) } & $\begin{array}{l}\text { Tilth } \\
\text { Index }\end{array}$ \\
\cline { 2 - 4 } & Wheat & Faba bean & \\
\hline P2 & 1410.75 & 816.92 & 0.52 \\
\hline P4 & 1496.15 & 921.74 & 0.55 \\
\hline P6 & 1896.41 & 1203.68 & 0.59 \\
\hline P8 & 2250.32 & 1026.52 & 0.67 \\
\hline Pm & 2375.82 & 1068.95 & 0.71 \\
\hline L.S.D. 0.05 & 164.87 & 47.72 & 0.049 \\
\hline
\end{tabular}

followed by (Pm), (P8), (P4) and (P2), respectively. The lowest grain yield of both wheat and faba bean were obtained with (P2) treatment which showed a poor soil physical properties that influenced both wheat and faba bean crops. The differences in wheat and faba bean yields among treatments were obtained. Wheat yield show no significant difference between (P8) and (Pm), while the differences between them and the other treatments were significant. On the other hand, moldboard plough or chisel plough (by eight passes) obtained the maximum yield, while faba bean obtained its maximum yield with chisel plough (by six passes).

\subsection{Tilth index (TI)}

Effect of tillage practices on (TI) is presented in Table (5). The (TI) is varying with the applied tillage treatment. (TI) ranges between 0.52 and 0.71. According to the model of Singh et al., (1992) it is proposed that a tilth index in the range of 0.8 to is optimal for crop production and that one less than 0.50 is poor. In the current study the highest (TI) value is obtained with moldboard plough. Singh et al., (1992), Tapela and Colvin, (1998) and Abou Yuossef, (2005) found that (TI) for moldboard plough system was higher than chisel plow system. No significant difference however, was found between the (TI) values of (Pm) and (P8). The lowest (TI) value was obtained with (P2). Data show that the highest grain yield of wheat was associated with the maximum (TI) value of (0.71) obtained with (Pm). While, the highest grains yield of faba bean was associated with (TI) value of (0.59) which obtained with (P6) treatment. These results indicate that wheat yield increased as (TI) increased, while faba bean yield decreased as (TI) increased. Wheat yield matches well with (TI) while faba bean yield did not match well with the (TI). This trend may be due to the nature of faba bean roots. The relationships between (TI) and yields of wheat and faba bean were performed. A 
second order (quadratic) type shows a highly significant correlation between (TI) and the yield of wheat, while the correlation with faba bean yield was much lower.

$$
\begin{aligned}
& \mathrm{Y}(\text { wheat })=-6129+21040(\mathrm{TI})-12760(\mathrm{TI})^{2} \\
& \mathrm{R} 2=0.983 \\
& \mathrm{Y}(\text { faba bean })=-9049+32100(\mathrm{TI})-25240(\mathrm{TI})^{2} \\
& \mathrm{R} 2=0.708
\end{aligned}
$$

\section{Conclusion}

Soil physical properties such as bulk density, penetration resistance and soil aggregates changed by the applied tillage system. The tilth index based upon these physical properties can determine the proper tillage method that improves these soil properties. These soil properties can affect root growth, root distributions and in turn influence crop growth and crop yield. In the current study the studied tillage practices influenced the wheat and Faba bean yields; moldboard plough followed by chisel plough, by eight passes, had the highest yield of wheat, while the highest yield of faba bean was obtained with chisel plough by six passes followed by moldboard plough. The yield of wheat increased as tilth index increased, while the yield of faba bean increased as tilth index increased to a certain value and decreased as tilth index increased. These results indicate that the energy require for the tillage of Faba bean crop can be saved. Tilth index should be calculated for different soil types, soil tillage practices and different crops. From its value it can be optimize the tillage practices needed for the maximum yield of the crop. Tilth index can also help in reducing labor and energy required for the management and this could lead to a reduction in production costs.

\section{REFERENCES}

Abou Youssef M.F. (2005). Tilth index: An approach to quantifying soil tilth in some calcareous soils. Egypt. J. Appi. Sci., 20 (3): 340-356.

Brady N.C.(1984). The Nature and Properties of Soils, $9^{\text {th }}$ (Ed.) Macmillan, New York.

Cassel D.K., Raczkowski C.W. and Denton H.P. (1995). Tillage effects on corn production and soil physical properties. Soil Sci. Soc. Am. J.59:1436-1443.

Cruse M.R. and Colvin T.S. (1989). Effect of different tillage systems on energy conservation. Progress Report, Integrated farm Management Demonstration program. Ames, Iowa: Iowa State University.
De Costa W.A.J.M., Dennet M.D., Ratnaweera U. and Nyalemegbe K. (1997). Effects of different water regimes on field-grown determinate and indeterminate faba bean (Vicia faba L.).I, canopy growth and biomass production. Field Crops Research, 49:83-93.

Gupta R.P. (1986). Criteria for physical rating of soils in relation to crop production. XIII International Soil Science Society congress, 13-20 August 1986, Hamburg. Hamburg Trans., pp. 69-70.

Hammel J.E. (1989). Long term tillage and crop rotation effects on bulk density and soil impedance in northern Idaho. Soil Sci. Soc. Am. J., 53: 1515-1519.

Hillel D. (1982). Introduction to Soil Physics. Orlando, FL. Academic Press, Inc.

Jumikis A.R. (1962). Soil Mechanics. Princeton, N.J.: Van Nostrand.

Karlen D.L., Erbach D.C., Kaspar T.C, Colvin T.S., Berry E.C. and Timmons D.R. (1990). Soil tilth: A review of past perceptions and future needs. Soil Sci. Soc. Am. J. 54: 153161.

Klute A. (1986). Water retention: Laboratory methods p.635-662. Methods of soil Analysis, Part $1,2^{\text {nd }}$ Ed. ASA and SSSA, Madison. WI, U.S.A.

Liu C. and Evett J.B. (1990). Soil properties $2^{\text {nd }}$

Ed.: Testing Measurement and

Evaluation. Englewood Cliffs, N.J.: Prentice Hall.

Page A.L., Miller R.H. and Keeney D.R. (Ed) (1982). Methods of Soil Analysis. Part-2 Chemical and Microbiological Properties $2^{\text {nd }}$ Ed. Amer. Soc. of Agron. Madison, Wisconsin, U.S.A.

Plaster E.J. (1985). Soil Science and Management. Belmar. Albany. N.y.

Schafer R.L., Johnson C.E., Elkins C.B., Hendrick J.D. (1985). Prescription tillage: The concept and examples. J. Agric. Eng. Res. 32: 123-129.

Singh K.K. (1991). Decision Support System for Soil Tilth Assessment. Ph.D. diss. Ames, Iowa: Iowa State Univ.

Singh K.K. and Colvin T.S. (1990). Tilth quantification of a Bangkok soil. In Proc. International Agricultural Engineering Conference and Exhibition, Vol. 3: 1057-1066. Bangkok. Thailand, 3-6 December. 
Singh K.K. and Colvin T.S. (1992). Tilth Index and crop yield. ASAE paper No. 921023. ASAE, St. Joseph, MI.

Singh K.K., Colvin T.S., Erabch D.C. and Mughal A.Q. (1992). Tilth index: An approach to quantifying soil tilth. Trans. of ASAE 35: 1777-1785.

Taieb A.Z. (1998). Effect of different tillage methods on some physical properties of soil and sunflower yield. Misr J. of Agric. Eng., 15: 159-173.

Tapela M. and Colvin T.S. (1998). The soil tilth index. An evaluation and proposed modification. Trans. ASAE 44 (4), 4348.
Tapela M. and Colvin T.S. (2002). Quantifying seed bed condition using soil physical properties. Soil and Tillage Res. 64: 203-210.

Tripathi R.P., Sharma P. and Singh S. (2005). Tilth index: An approach to optimize tillage in rice-wheat system. Soil and Tillage Res. 80:125-137.

Vyn T.J. and Raimbault B.A. (1993). Long-term effect of five tillage systems on corn response and soil structure. Agron.J.85:1074-1079.

Wray W.K. (1986). Measuring Engineering properties of soil. Englewood Cliffs, NJ: Prentice Hall, Inc.

$$
\begin{aligned}
& \text { قياس كفاءة حرث التربة لمحصولى القمح والفول بأستخدام دليل الحرث } \\
& \text { منال أبو المعاطى النادى- محمد فتحى أبو يوسف* } \\
& \text { قسم الأر اضى-كلية الزر اعة-جامعة القاهرة } \\
& \text { *قم صيانة الأر اضى - مركز بحوث الصحر اءــ القاهرة- الجيزة - مصرة. }
\end{aligned}
$$

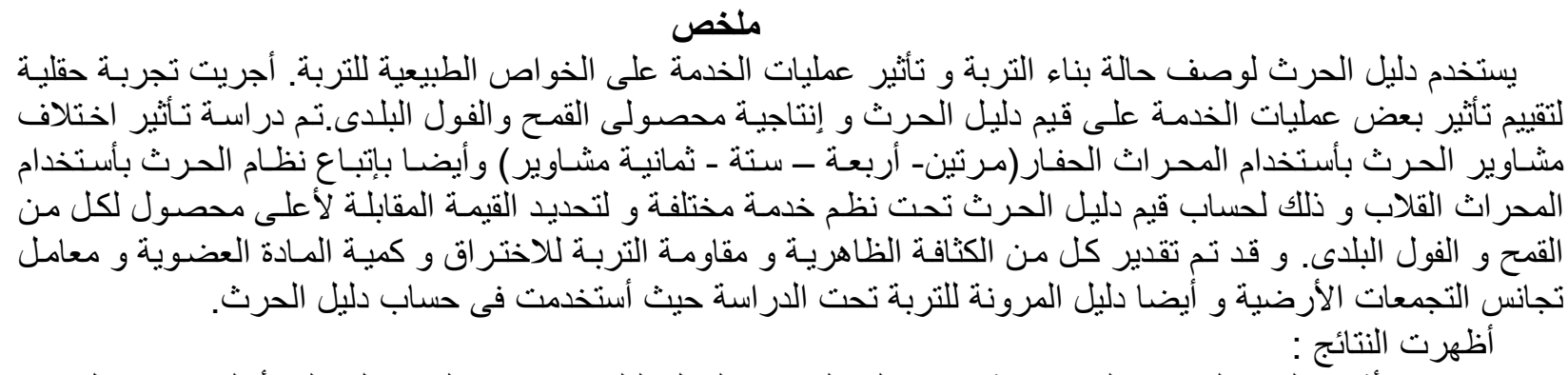
1- اختلاف تأثثير عمليات الحرث على إنتاجية محصولى القمح و الفول البلدى. فقد تم الحصول على أعلى محصول عند

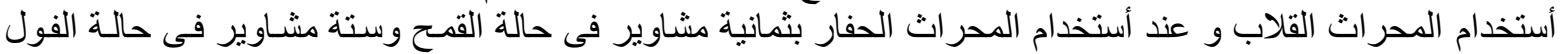

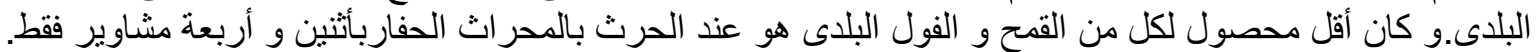

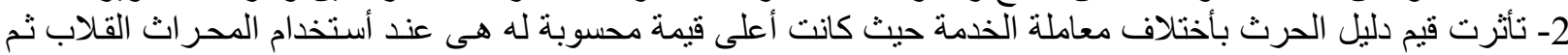

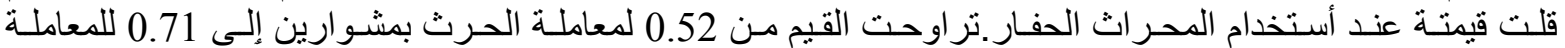
بالمحر اث القلاب. 3- هنالك زيادة في محصول القمح مع زيادة قيمة دليل الحرث ,بينما لم يتبع الفول البلدى هذا الاتجاة.

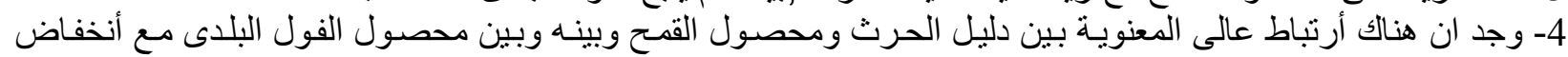

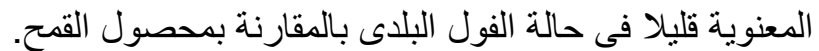

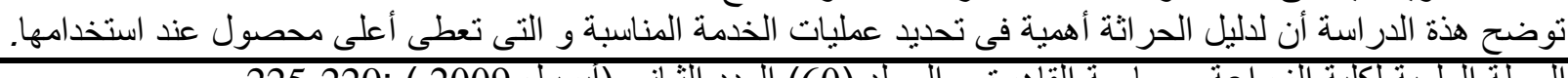

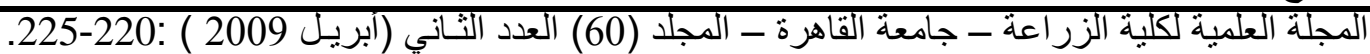

